\title{
Penyuluhan Metode Demonstrasi Cara Diversifikasi Olahan Ikan Tuna (Thunnini) Pada Pengolah Di Kecamatan Morotai Selatan Kabupaten Pulau Morotai Provinsi Maluku Utara
}

\author{
[Demonstration How to Diversificate Tuna Fish (Thunnini) Process to Improve \\ Processing Skills In South Morotai District Morotai Island District, \\ North Maluku Province]
}

\section{Sarni Malagapi, Tatty Yuniarti, Ganjar Wiryati}

Program Studi Penyuluhan Perikanan, Politeknik Ahli Usaha Perikanan Jl. Cikaret No. 2 Bogor Selatan Kota Bogor

\begin{abstract}
Abstrak
Kabupaten Pulau Morotai memiliki potensi perikanan yang mumpuni dalam bidang penangkapan dan pengolahan. Potensi perikanan dapat dikembangkan dengan cara meningkatkan peranan sumber daya manusia yang menjadi motor penggerak bagi aspek perikanan. Tujuan penelitian adalah mengamati perubahan pengetahuan, sikap, dan ketrampilan serta tingkat adopsi inovasi Poklahsar Datepi mengenai diversifikasi produk olahan perikanan dengan bahan baku ikan tuna melalui penyuluhan. Penelitian dilakukan mulai tanggal 2 Maret sampai dengan tanggal 15 Mei 2020. Tahapan penyuluhan diawali dengan penetapan lokasi dan dan sasaran penyuluhan, sosialisasi kegiatan penyuluhan, penyuluhan diversivikasi olahan ikan menggunakan metode demonstrasi cara, pengamatan difusi, dan adopsi, serta evaluasi penyuluhan. Hasil penelitian kegiatan penyuluhan menunjukkan pada penyuluhan pembuatan diversifikasi produk olahan yaitu krispi ikan tuna terdapat peningkatan aspek pengetahuan sebesar $37 \%$, aspek sikap sebesar $14 \%$ dan pada demonstrasi pembuatan nugget, terjadi peningkatan pada aspek pengetahuan sebasar 26,41 \%, aspek sikap sebesar 13,6\%. Perubahan pada aspek keterampilan menunjukkan kondisi keterampilan sebelumnya cukup terampil menjadi terampil dalam pemilihan bahan baku sampai membentuk olahan krispi dan nugget. Diversifikasi olahan ikan tuna berupa nuget dan krispi ikan tuna dapat diterima dengan baik oleh poklahsar.
\end{abstract}

Kata kunci: krispi ikan tuna; nuget ikan tuna; penyuluhan; poklahsar

\begin{abstract}
Morotai Island Regency has excellent fishery potential in the fishing and processing sectors. Fishery potential can be developed by increasing the role of human resources as the driving force for fisheries aspects. The research objective was to observe changes in knowledge, attitudes and skills as well as the level of adoption of Poklahsar Datepi innovation regarding the diversification of processed fishery products with tuna as raw material through counseling. The research was conducted from March 2 to May 15, 2020. The extension stages began with the determination of the location and target of the extension, socialization of extension activities, extension of the diversification of processed fish using demonstration methods, diffusion observation, and adoption, and evaluation of extension. The results of the research on extension activities showed that in the extension of the diversification of processed products, namely tuna crispy there was an increase in the knowledge aspect by $37 \%$, the attitude aspect by $14 \%$ and at the demonstration of making nuggets, there was an increase in the knowledge aspect by $26.41 \%$, the attitude aspect by $13,6 \%$. Changes in the skill aspect show that the previous skill conditions were quite skilled to be skilled in selecting raw materials to form crispy and nugget processing. The diversification of processed tuna in the form of nuggets and crispy tuna has been well received by poklahsar..
\end{abstract}

Keywords: counselling; poklahsar; tuna nuget; tuna crispy 


\section{Penulis Korespondensi}

Sarni Malagapi | sarnimalagapi98@gmail.com

\section{PENDAHULUAN}

Potensi bidang perikanan masih banyak yang belum tersentuh untuk dikembangkan secara maksimal, potensi perikanan yang ada di berbagai daerah sangat beragam. Kabupaten Pulau Morotai terletak di ujung paling Utara Provinsi Maluku Utara merupakan kabupaten baru hasil pemekaran dari Kabupaten Halmahera Utara berdasarkan Undang-Undang Nomor 53 Tahun 2008 tentang Pembentukan Kabupaten Pulau Morotai Provinsi Maluku Utara. Secara astronomis Kabupaten Pulau Morotai terletak di antara $2^{\circ} 00^{\prime} 00^{\prime \prime}$ sampai dengan $2^{\circ} 40^{\prime}$ 00" Lintang Utara dan $128^{\circ} 15^{\prime} 00^{\prime \prime}$ sampai dengan $128^{\circ} 48^{\prime} 00^{\prime \prime}$ Bujur Timur. Sumber daya alam dan sumber daya manusia meliputi luas wilayah daratan Kabupaten Pulau Morotai mencapai 2,330.6 $\mathrm{km}^{2}$ yang terdiri dari 33 pulau. Jumlah penduduk Kabupaten Pulau Morotai hanya sekitar 73,630 jiwa, dimana sekitar 4,000 orang berprofesi sebagai nelayan baik aktif maupun sambilan (BPS 2017). Informasi mengenai sumber daya alam dan manusia diperlukan untuk mengidentifikasi permasalahan perikanan suatu wilayah (Putri, Yuniarti, dan Dewi 2019)
Masyarakat pengolah di Kecamatan Morotai Selatan sebagian besar telah membentuk kelompok namun kelompok yang ada belum menerapkan 8 fungsi kelompok sesuai dengan Pedoman Umum Penumbuhan dan Pengembangan Kelembagaan Pelaku Utama Perikanan. Produksi olahan yang dihasilkan berupa abon ikan tuna mencapai 2.880 ton/tahun. Pengolah perikanan di Kecamatan Morotai Selatan belum memiliki pengetahuan dalam diversifikasi olahan ikan. Diversifikasi olahan ikan dapat meningkatkan pendapatan lebih banyak dibandingkan dengan satu atau dua olahan ikan dengan bahan baku yang sama. Contoh diversifikasi dari bahan baku ikan bandeng, yaitu dibuat berbagai olahan seperti produk olahan bakwan bandeng, bakso bandeng, nugget bandeng, kaki naga, otak-otak bandeng, galantin, otak-otak ikan dan (Amdar, Anas, dan Yuniarti 2019)

Upaya mendorong percepatan pembangunan dan peningkatan kemampuan sumberdaya manusia pada kegiatan pengolahan hasil perikanan dapat dilakukan engan penyuluhan. Penyuluhan yang tepat dapat mempercepat adopsi inovasi teknologi perikanan pada sasaran masyarakat 
perikanan (Nursahla et al. 2019). Tujuan penelitian adalah melakukan penyuluhan mengenai diversifikasi produk olahan perikanan dari bahan baku dari ikan tuna dan mengevaluasi hasil penyuluhan dari aspek pengetahuan, dan sikap pengolah terhadap kelompok pengolah dan pemasar di Kecamatan Morotai Selatan.

\section{BAHAN DAN METODE}

\section{Waktu dan Lokasi penelitian}

Penelitian dilaksanakan pada tanggal 2 Maret 2020 sampai dengan tanggal 15 Mei 2020 di Kecamatan Morotai Selatan Kabupaten Pulau Morotai Provinsi Maluku Utara.

\section{Populasi dan Sampel penelitian}

Populasi adalah pengolah di Kecamatan Morotai. Sampel penelitian ditentukan secara purposive sampling yaitu menunjuk pengolah dalam kelompok yang berminat membuat olahan ikan selain abon ikan tuna. Metode ini dilakukan dengan pemilihan sampel/responden berdasarkan pada karakteristik kelompok dengan olahan yang tidak bervariasi. Sampel pada penelitian ini sebagai sasaran penyuluhan adalah anggota Kelompok Pengolah Dapeti berjumlah sepuluh orang.

\section{Program Penyuluhan dan Evaluasi}

Program penyuluhan yang dilaksanakan selama di Kecamatan Morotai Selatan Kabupaten Pulau Morotai meliputi: sosialisasi cara mengolah ikan yang baik, demonstrasi cara pembuatan nugget ikan tuna, demonstrasi cara pembuatan krispi ikan tuna dan evaluasi hasil penyuluhan. Inovasi produk olahan krispi dan nuget ikan tuna yang diberikan adalah hal yang dianggap baru karena belum dilakukan pada kelompok pengolah perikanan di Kecamatan Morotai Selatan, walaupun telah dilakukan di daerah lain. Inovasi tersebut adalah cara pengolahan nuget ikan dan krispi ikan. Inovasi ini diberikan

Tabel 1. Bahan-bahan pembuatan nuget ikan tuna

\begin{tabular}{clcc}
\hline No & Bahan & Satuan & Jumlah \\
\hline 1 & Ikan tuna & $\mathrm{g}$ & 700 \\
2 & Telur & butir & 7 \\
3 & Tepung roti & $\mathrm{g}$ & 500 \\
4 & Tepung tapioka & $\mathrm{g}$ & 350 \\
5 & Bawang putih & siung & 6 \\
7 & Garam dan merica & $\mathrm{g}$ & 30 \\
8 & Minyak goreng & Sendok & 5 \\
\hline
\end{tabular}


dengan pertimbangan kriteria memiliki keuntungan relatif (Relative advantage), kesesuaian (Compatibility), kerumitan (Complexity), dapat dicoba/diterapkan (Triability) dan kemungkinan diamati (Observability). Bahan pembuatan nuget ikan tuna disajikan pada Tabel 1.

Pembuatan nuget ikan tuna yaitu dengan cara menghaluskan daging ikan tuna, kemudian diuleni dengan garam hingga terbentuk seperti jeli ikan. Adonan daging ikan tuna ditambah 3 butir telur yang telah diaduk sebelumnya. Selanjutnya ditambahkan bumbu dan tepung tapioka secara perlahan. Adonan yang tercampur rata, dikukus dan dicetak. Setelah dingin, digulingkan dalam telur kemudian dibalurkan dengan tepung roti. Adonan dapat digoreng setengah matang untuk disimpan dalam freezer atau digoreng matang untuk disajikan.
Pembuatan krispi ikan tuna sebagai materi demonstrasi cara pada kegiatan penyuluhan terdiri dari beberapa langkah. Langkah pertama adalah memotong daging ikan tuna kurang lebih sebesar $3 \times 3 \mathrm{~cm}$, diberi jeruk nipis. Selanjutnya, daging ikan tuna direndam dalam larutan bumbu, kemudian ditiriskan. Daging ikan dimasukan dalam larutan tepung terigu dan digulingkan dalam campuran tepung beras dan tepung maizena, selanjutnya daging ikan tuna digoreng hingga berwarna kuning dan renyah. Bahan pembuatan krispi ikan tuna disajikan pada Tabel 2.

\section{Evaluasi hasil penyuluhan}

Evaluasi penyuluhan dilakukan untuk mengukur dampak kegiatan penyuluhan yang telah dilakukan, berupa aspek sikap, pengetahuan dan keterampilan. Dampak yang diharapkan

Tabel 2. Bahan-bahan pembuatan krispi ikan tuna

\begin{tabular}{llcc}
\hline No & Bahan & Satuan & Jumlah \\
\hline 1 & Ikan tuna & $\mathrm{g}$ & 500 \\
2 & Tepung terigu & $\mathrm{g}$ & 300 \\
3 & Maizena & $\mathrm{g}$ & 150 \\
4 & Tepung tapioca & $\mathrm{g}$ & 150 \\
5 & Tepung Beras & $\mathrm{g}$ & 150 \\
6. & Lada bubuk & $\mathrm{g}$ & 15 \\
7 & Ketumbar bubuk & $\mathrm{g}$ & 30 \\
8 & Jeruk nipis & buah & 1 \\
9 & Garam & Sendok makan & 5 \\
\hline
\end{tabular}


berupa perubahan ke arah yang lebih baik setelah penyuluhan tersebut. Dampak penyuluhan yang diamati per minggu adalah tahapan adopsi inovasi olahan ikan tuna. Tahapan tersebut adalah (1) sadar: Pertama kali mendengar tentang inovasi; (2) minat: mencari informasi lebih lanjut; (3) menilai: menimbang kelebihan dan kekurangan penggunaan inovasi; (4) mencoba: menguji sendiri inovasi pada skala kecil; (5) menerapkan: menerapkan inovasi setelah melihat hasil uji mengalami peningkatan.

Metode evaluasi penyuluhan adalah deskriptif kualitatif dengan pengumpulan data melalui observasi dan wawancara, menggunakan alat pengumpul data berupa daftar pertanyaan dalam bentuk kuesioner. Data yang diamati berupa karakteristik responden dan respon terhadap penyuluhan yang diberikan kepada kelompok. Materi penyuluhan adalah diversifikasi olahan ikan tuna. Data yang di kumpulkan berupa data primer yang diperoleh dari pelaku utama dan pelaku usaha, pemasar, penyuluh dan pihak terkait data sekunder di peroleh dari BPS, kantor DKP dan internet serta sumber pustaka lainnya. Data yang diperoleh dianalisa statistik secara sederhana menggunakan software Exell 2016 dari Microsoft dan ditampilkan dalam tabel dan diagram.

\section{HASIL DAN PEMBAHASAN}

\section{Hasil}

Karakteristik Sasaran

Karakteristik sasaran penelitian penyuluhan ini terdiri dari umur, pendidikan formal dan pengalaman usaha sasaran. Adapun karakteristik sasaran penyuluhan yaitu anggota Kelompok Datepi, Kecamatan Morotai Selatan, Kabupaten Pulau Morotai Provinsi Maluku Utara dapat dilihat pada Tabel 3.

Tabel 3. Karakteristik Sasaran Penyuluhan (Kelompok Datepi) di Kecamatan Morotai Selatan, Kabupaten Pulau Morotai

\begin{tabular}{ccccccccc}
\hline & Usia & \multicolumn{4}{c}{ Tingkat Pendidikan } & \multicolumn{3}{c}{ Pengalaman Usaha } \\
\hline Kategori & $\begin{array}{c}\text { Standar } \\
\text { (Tahun) }\end{array}$ & $\begin{array}{c}\text { Jumlah } \\
\text { (orang) }\end{array}$ & Kategori & $\begin{array}{c}\text { Standar } \\
\text { (Pen. Formal) }\end{array}$ & $\begin{array}{c}\text { Jumlah } \\
\text { (orang) }\end{array}$ & Kategori & $\begin{array}{c}\text { Sandar } \\
\text { (Tahun) }\end{array}$ & $\begin{array}{c}\text { Jumlah } \\
\text { (orang) }\end{array}$ \\
\hline Muda & $X \leq 39$ & 3 & Rendah & SD $\geq X \leq$ SMP & 6 & Baru & $X<1$ & - \\
Sedang & $40 \geq X \leq 53$ & 3 & Sedang & $X=$ SMA & 4 & Sedang & $1 \geq X \leq 7$ & 10 \\
Tua & $>54$ & 4 & Tinggi & $X \geq D 3$ & - & Lama & $>7$ & - \\
\hline \multicolumn{2}{l}{ Total Jumlah Sasaran } & 10 & \multicolumn{2}{c}{ Total Jumlah Sasaran } & 10 & Total Jumlah Sasaran & 10 \\
\hline
\end{tabular}


Evaluasi Aspek Pengetahuan Demonstrasi Cara Pengolahan Nugget Ikan Tuna

Hasil evaluasi pengetahuan pembuatan nuget ikan tuna sasaran dilihat dari Pre Test dan Post Test. Pada Pre Test diperoleh rata-rata nilai awal aspek pengetahuan sebesar 8,3 atau $59,3 \%$ dari 14 soal yang diberikan. Peningkatan sebesar $26,41 \%$. lebih jelasnya hasil evaluasi dapat dilihat pada Gambar 1.
Evaluasi Aspek Sikap Demonstrasi Cara pengolahan Nugget Ikan Tuna

Evaluasi sikap dilakukan untuk mengetahui sejauh mana tingkat persetujuan sasaran dan tingkat perubahan prilaku sasaran setelah menerima inovasi. Evaluasi sikap dilakukan sebelum memberikan inovasi (Pre Test) dan setelah pemberian inovasi (Post Test). Hasil evaluasi sikap dalam hal ini Pre Test dapat dilihat pada Gambar 2.

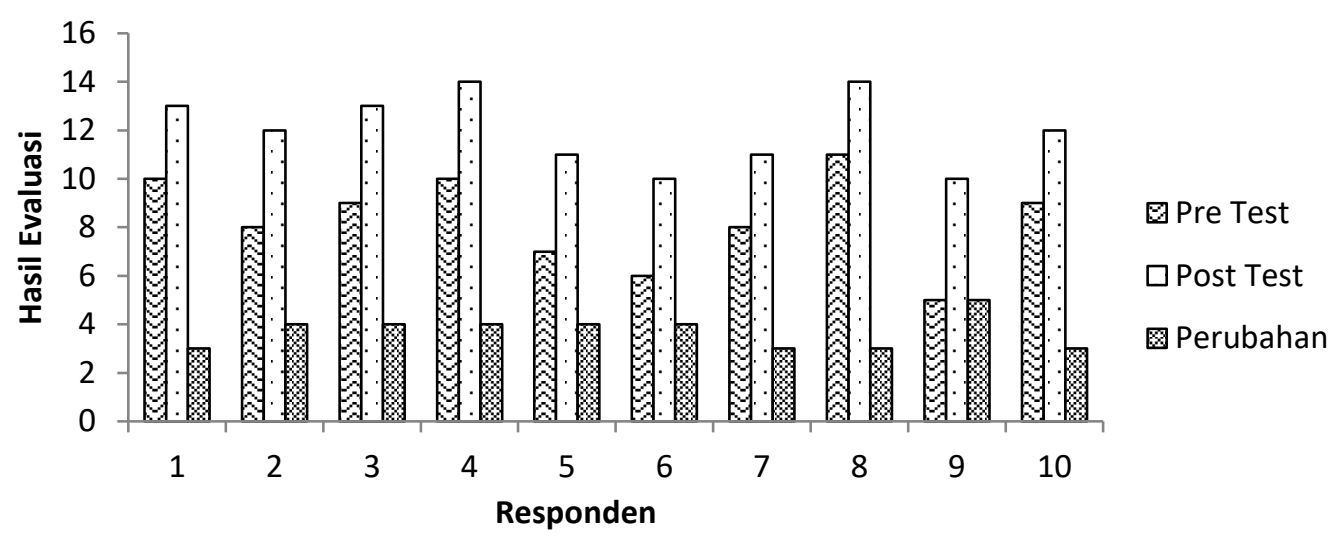

Keterangan : 1. Fatmawati, 2. Siti Aisya, 3. Mahmidar Halal, 4. Kiran, 5. Ati Larat, 6. Ratna, 7. Sahrin, 8. Nursuni. 9 Nabsia, 10. Nuryani.

Gambar 1. Hasil Evaluasi Aspek Pengetahuan Pembuatan Nuget Ikan

Pre Test

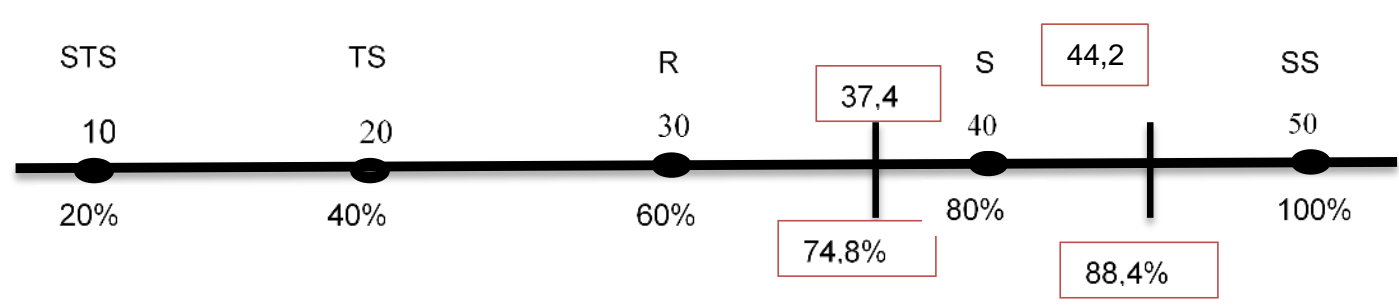

Gambar 2.Garis Kontinum Aspek Sikap pembuatan Olahan Nugget Ikan Tuna 
Hasil evaluasi akhir sikap sasaran mengalami perubahan pada tingkat persetujuan. Sebelumnya tingkat persetujuan sasaran memiliki nilai sebesar $37,4(74,8 \%)$ atau berada pada tingkat setuju. Setelah dilaksanakannya penyuluhan olahan nugget ikan dan evaluasi akhir didapatkan perubahan sikap sasaran dengan nilai menjadi 44,2 $(88,4 \%)$ atau berada pada tingkat sangat setuju dengan kisaran nilai $40-50$. Perbandingan persentase hasil Pre Test dan Post Test dapat dilihat pada Gambar 3.

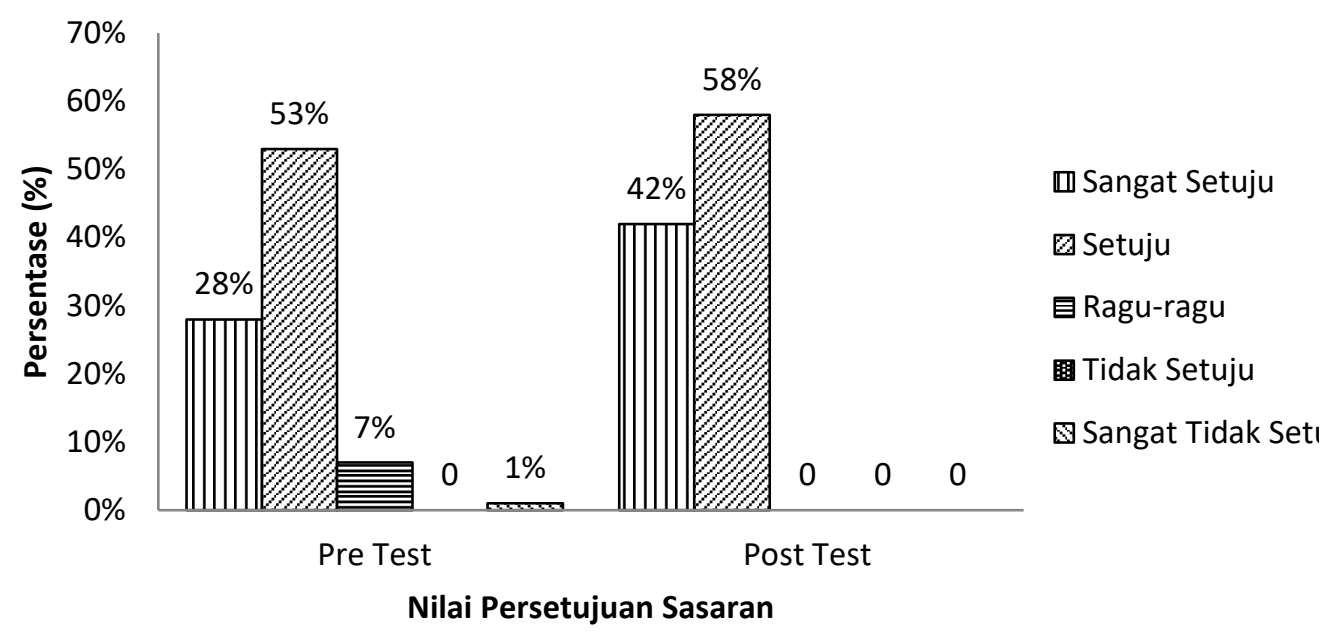

Gambar 3. Hasil Evaluasi Sikap Tingkat Persetujuan pada pembuatan Nugget Ikan

Tabel 4.Evaluasi Aspek Keterampilan (Pre Test) pembuatan olahan Nuget

\begin{tabular}{|c|c|c|c|c|}
\hline \multirow[b]{2}{*}{ No } & \multirow[b]{2}{*}{ Pernyataan } & \multicolumn{3}{|c|}{ Kemampuan } \\
\hline & & $\begin{array}{l}\text { Terampil (T) } \\
\text { (Orang) }\end{array}$ & $\begin{array}{l}\text { Cukup } \\
\text { Terampil (CT) } \\
\text { (Orang) }\end{array}$ & $\begin{array}{c}\text { Tidak } \\
\text { Terampil (TT) } \\
\text { (Orang) }\end{array}$ \\
\hline 1. & $\begin{array}{l}\text { Pemilihan bahan baku olahan } \\
(\mathrm{T}=1 \text { menit, } \mathrm{CT}=2 \text { menit, } \\
\mathrm{TT}=3 \text { menit })\end{array}$ & 0 & s. or & r o or \\
\hline 2. & $\begin{array}{l}\text { Membuat adonan surimi ( } \mathrm{T}=7 \text { menit, } \mathrm{CT} \\
=10 \text { menit, } \mathrm{TT}=15 \text { menit) }\end{array}$ & 0 & 3 & 7 \\
\hline 3. & $\begin{array}{l}\text { Pengambilan keputusan kapan adonan } \\
\text { selesai dikukus } \\
\text { ( } \mathrm{T}=2 \text { menit, } \mathrm{CT}=4 \text { menit, } \\
\mathrm{TT}=5 \text { menit) }\end{array}$ & 0 & 3 & 7 \\
\hline 4. & $\begin{array}{l}\text { Membuat adonan premix ( } T=6 \text { menit, } C T \\
=10 \text { menit, } \mathrm{TT}=14 \text { menit) }\end{array}$ & 0 & 4 & 6 \\
\hline 5. & $\begin{array}{l}\text { Membentuk olahan nugget rapi dan } \\
\text { menarik }(T=6 \text { menit, } \mathrm{CT}=10 \text { menit, } \mathrm{TT}= \\
14 \text { menit })\end{array}$ & 0 & 6 & 4 \\
\hline
\end{tabular}


Tabel 5. Rekapan Hasil Penilaian Evaluasi Akhir Aspek Keterampilan pembuatan Nuget Ikan

\begin{tabular}{|c|c|c|c|c|}
\hline \multirow[b]{2}{*}{ No } & \multirow[b]{2}{*}{ Pernyataan } & \multicolumn{3}{|c|}{ Kemampuan } \\
\hline & & $\begin{array}{c}\text { Terampil (T) } \\
\text { (Orang) }\end{array}$ & $\begin{array}{l}\text { Cukup } \\
\text { Terampil (CT) } \\
\text { (Orang) }\end{array}$ & $\begin{array}{l}\text { Tidak Terampil } \\
\text { (TT) (Orang) }\end{array}$ \\
\hline 1. & $\begin{array}{l}\text { Pemilihan bahan baku olahan } \\
(\mathrm{T}=1 \text { menit, } \mathrm{CT}=2 \text { menit, } \\
\mathrm{TT}=3 \text { menit })\end{array}$ & 8 & 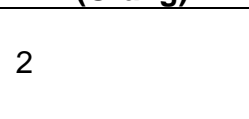 & 0 \\
\hline 2. & $\begin{array}{l}\text { Membuat adonan surimi ( } \mathrm{T}=7 \text { menit, } \mathrm{CT}= \\
10 \text { menit, TT }=15 \text { menit) }\end{array}$ & 7 & 2 & 1 \\
\hline 3. & $\begin{array}{l}\text { Pengambilan keputusan kapan adonen } \\
\text { selesai dikukus } \\
\text { ( } \mathrm{T}=2 \text { menit, } \mathrm{CT}=4 \text { menit, } \\
\text { TT }=5 \text { menit) }\end{array}$ & 9 & 1 & 0 \\
\hline 4. & $\begin{array}{l}\text { Membuat adonan premix ( } \mathrm{T}=6 \text { menit, } \mathrm{CT}= \\
10 \text { menit, } \mathrm{TT}=14 \text { menit) }\end{array}$ & 7 & 2 & 1 \\
\hline 5. & $\begin{array}{l}\text { Membentuk olahan nugget rapi dan menarik } \\
(\mathrm{T}=6 \text { menit, } \mathrm{CT}=10 \text { menit, } \mathrm{TT}=14 \text { menit })\end{array}$ & 8 & 1 & 1 \\
\hline
\end{tabular}

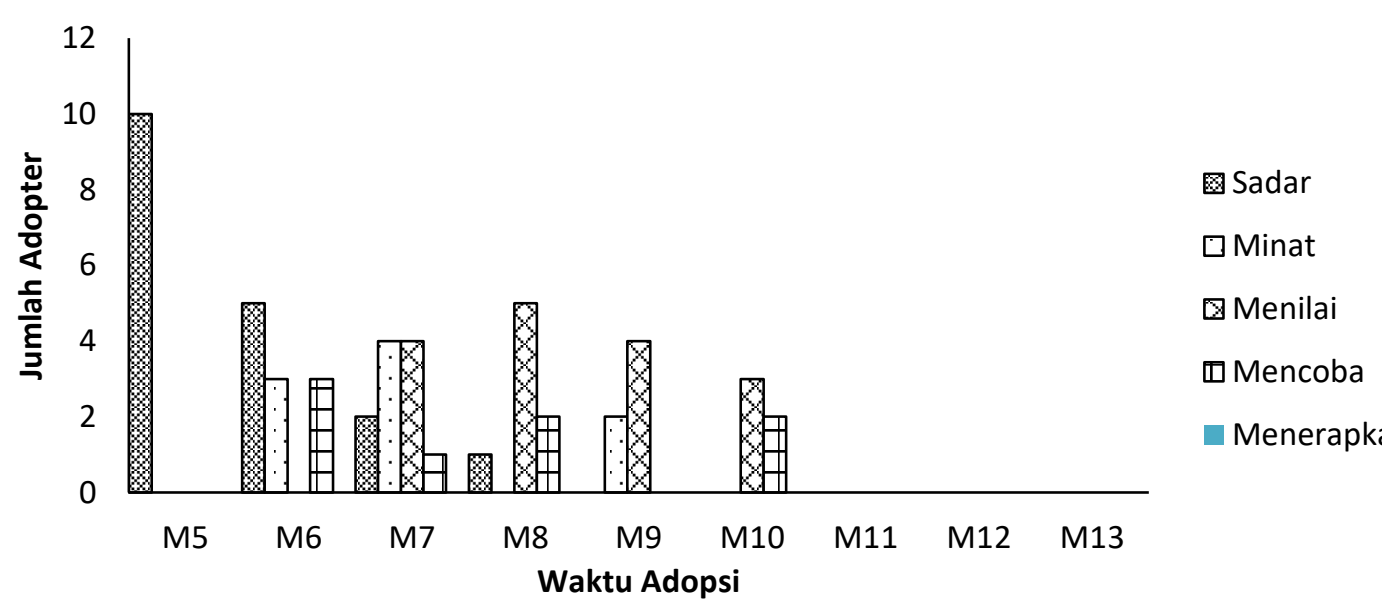

Gambar 4. Jumlah Adopter Inovasi dalam Satuan Minggu

Evaluasi Aspek Keterampilan

Demonstrasi Cara pengolahan Nugget Ikan Tuna

Evaluasi keterampilan pada kegiatan penyuluhan dilakukan untuk mengukur sejauh mana keterampilan yang dimiliki sasaran terhadap inovasi yang diberikan. Evaluasi keterampilan dilakukan dengan meperhatikan tiga kriteria yaitu terampil $(T)$, cukup terampil (CT) dan tidak terampil (TT). Penilaian dilakukan menggunakan telepon. Rekapitulasi evaluasi aspek keterampilan (Pre Test) dapat dilihat pada Tabel 4. Adapun rekapan hasil evaluasi akhir aspek keterampilan dapat dilihat pada Tabel 5 .

\section{Adopsi Inovasi Demonstrasi Cara Pengolahan Nugget Ikan Tuna}

Tingkat adopsi inovasi demonstrasi cara pengolahan nuget ikan tuna dapat dilihat pada Gambar 4. 
Evaluasi Aspek Pengetahuan Demonstrasi Cara Pembuatan Olahan Krispi Ikan

Hasil evaluasi pengetahuan dilihat dari Pre Test dan Post Test. Pada Pre Test didapatkan rata-rata nilai awal aspek pengetahuan sebesar 5,6 atau $56 \%$ dari 10 soal yang diberikan. Adapun setelah pelaksanaan Post Test didapatkan peningkatan dari nilai Pre Test sebelumnya dari 56\% menjadi $93 \%$. Perbedaan Pre Test dan Post Test lebih jelasnya dapat dilihat pada Gambar 5.
Evaluasi Aspek Sikap Demonstrasi Cara Pembuatan Olahan Krispi Ikan

Evaluasi sikap dilakukan untuk mengetahui sejauh mana tingkat persetujuan sasaran dan tingkat perubahan prilaku sasaran setelah menerima inovasi. Evaluasi sikap dilakukan sebelum memberikan inovasi (Pre Test) dan setelah pemberian inovasi (Post Test). Gambar 6 menunjukkan terjadinya peningkatan sikap menerima inovasi diversifikasi olahan krispi ikan tuna. Perbandingan persentase hasil Pre

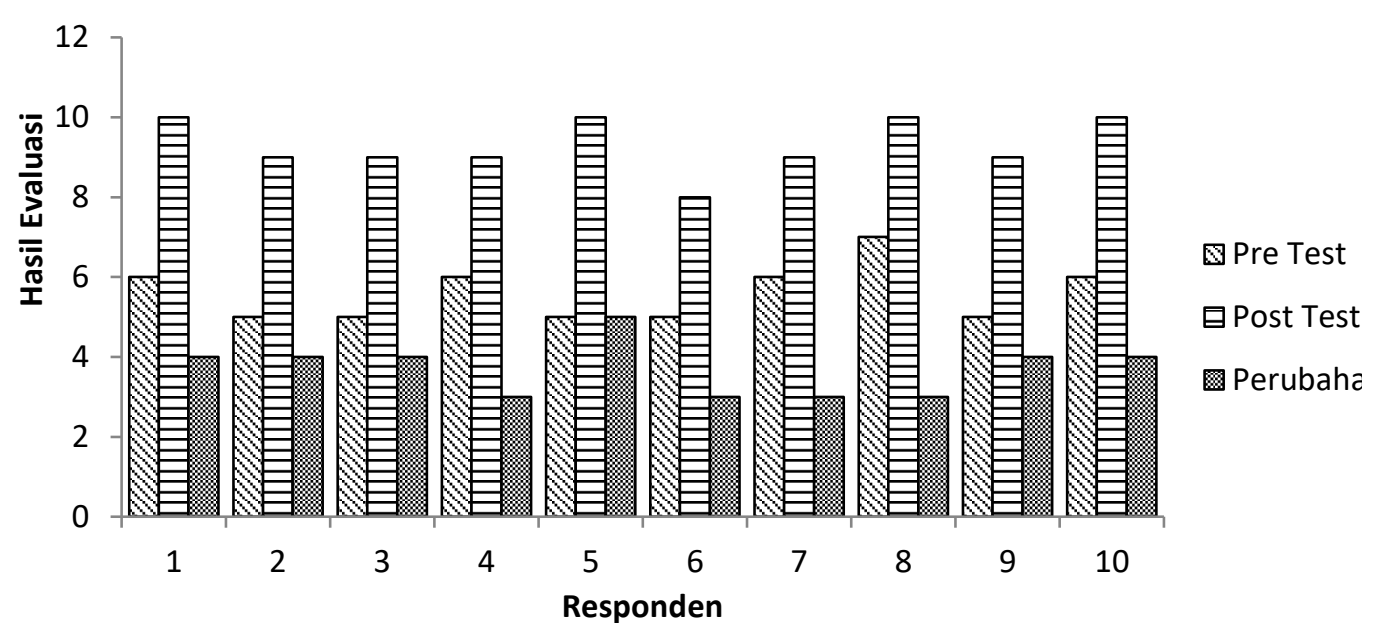

Keterangan : 1. Fatmawati, 2. Siti Aisya, 3. Mahmidar Halal, 4. Kiran, 5. Ati Larat, 6. Ratna, 7. Sahrin, 8. Nursuni. 9 Nabsia, 10. Nuryani.

Gambar 5. Perbedaan Pre Test dan Post Test Aspek Pengetahuan

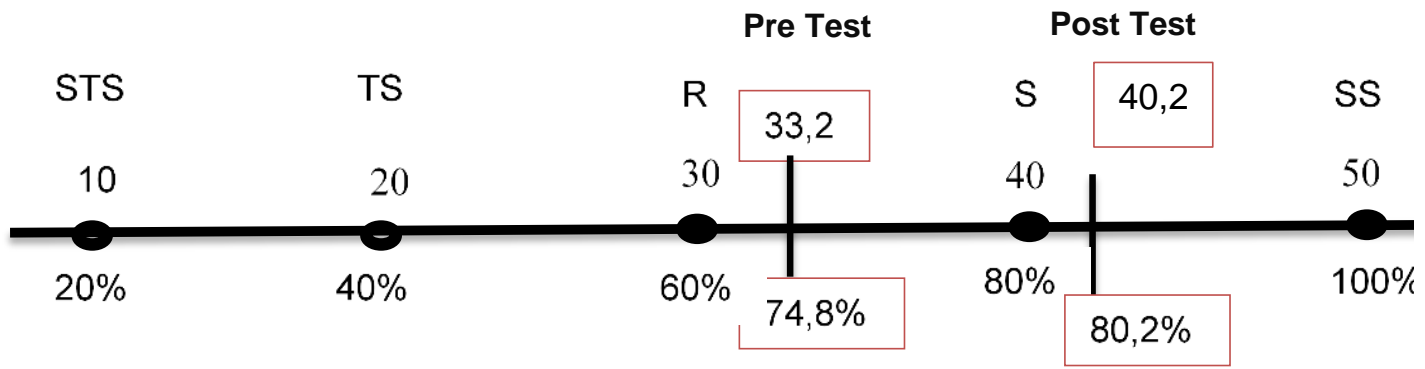

Gambar 6. Garis Kontinum Aspek Sikap Olahan Krispi Ikan Tuna 


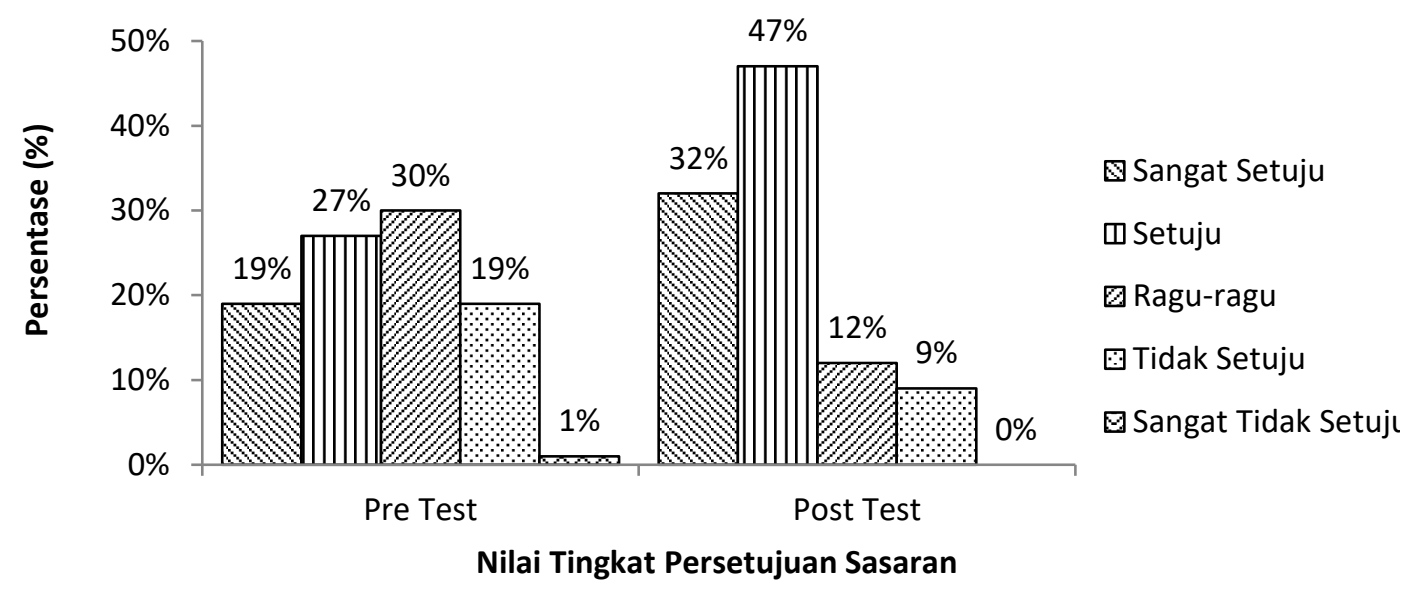

Gambar 7. Perbandingan Tingkat Persetujuan Evaluasi Sikap Demcar Krispi Ikan

Tabel 6.Evaluasi Aspek Keterampilan (Pre Test)

\begin{tabular}{|c|c|c|c|c|}
\hline \multirow[b]{2}{*}{ No } & \multirow[b]{2}{*}{ Pernyataan } & \multicolumn{3}{|c|}{ Kemampuan } \\
\hline & & $\begin{array}{l}\text { Terampil (T) } \\
\text { (Orang) }\end{array}$ & $\begin{array}{l}\text { Cukup } \\
\text { Terampil (CT) } \\
\text { (Orang) }\end{array}$ & $\begin{array}{l}\text { Tidak Terampil } \\
\text { (TT) (Orang) }\end{array}$ \\
\hline 1. & $\begin{array}{l}\text { Sasaran mampu menyiapkan bahan } \\
\text { dengan tepat dan cepat }(T=5 \text { menit, } \mathrm{CT} \\
=8 \text { menit, } \mathrm{TT}=12 \text { menit) }\end{array}$ & 0 & 5 & 5 \\
\hline 2. & $\begin{array}{l}\text { Sasaran mampu menguleni adonan } \\
\text { hingga kalis }(\mathrm{T}=6 \text { menit, } \mathrm{CT}=10 \text { menit, } \\
\mathrm{TT}=12 \text { menit })\end{array}$ & 0 & 6 & 4 \\
\hline 3. & $\begin{array}{l}\text { Sasaran mampu membuat krispi } 500 \mathrm{gr} \\
\text { dengan cepat dan tepat }(\mathrm{T}=5 \mathrm{menit}, \mathrm{CT} \\
=7 \text { menit, } \mathrm{TT}=10 \text { menit) }\end{array}$ & 0 & 4 & 6 \\
\hline
\end{tabular}

Test dan Post Test dapat dilihat pada gambar yang disajikan pada Gambar 7 .

\section{Evaluasi Aspek Keterampilan} Demonstrasi Cara Pembuatan Olahan Krispi lkan

\section{Evaluasi keterampilan pada} kegiatan penyuluhan dilakukan untuk mengukur sejauh mana keterampilan yang dimiliki sasaran terhadap inovasi yang diberikan. Evaluasi keterampilan dilakukan dengan memerhatikan tiga kriteria yaitu Terampil (T), Cukup Terampil (CT) dan Tidak Terampil (TT). Penilaian dilakukan menggunakan telepon. Rekapitulasi evaluasi aspek keterampilan (Pre Test) dapat dilihat pada Tabel 6. Tabel 7 menunjukkan hasil evaluasi akhir aspek keterampilan responden membuat krispi ikan tuna. 
Tabel 7. Hasil Evaluasi Akhir Aspek Keterampilan

\begin{tabular}{|c|c|c|c|c|}
\hline \multirow[b]{2}{*}{ No } & \multirow[b]{2}{*}{ Pernyataan } & \multicolumn{3}{|c|}{ Kemampuan } \\
\hline & & $\begin{array}{l}\text { Terampil (T) } \\
\text { (Orang) }\end{array}$ & $\begin{array}{l}\text { Cukup } \\
\text { Terampil (CT) } \\
\text { (Orang) }\end{array}$ & $\begin{array}{l}\text { Tidak Terampil } \\
\text { (TT) (Orang) }\end{array}$ \\
\hline 1. & $\begin{array}{l}\text { Sasaran mampu menyiapkan bahan } \\
\text { dengan tepat dan cepat ( } T=5 \text { menit, } C T \\
=8 \text { menit, } T T=12 \text { menit) }\end{array}$ & 4 & (1..... & 0 \\
\hline 2. & $\begin{array}{l}\text { Sasaran mampu menguleni adonan } \\
\text { hingga kalis }(T=6 \text { menit, } C T=10 \text { menit, } \\
\text { TT }=12 \text { menit })\end{array}$ & 5 & 5 & 0 \\
\hline 3. & $\begin{array}{l}\text { Sasaran mampu membuat krispi } 500 \mathrm{gr} \\
\text { dengan cepat dan tepat ( } \mathrm{T}=5 \text { menit, CT } \\
=7 \text { menit, TT }=10 \text { menit) }\end{array}$ & 6 & 4 & 0 \\
\hline
\end{tabular}

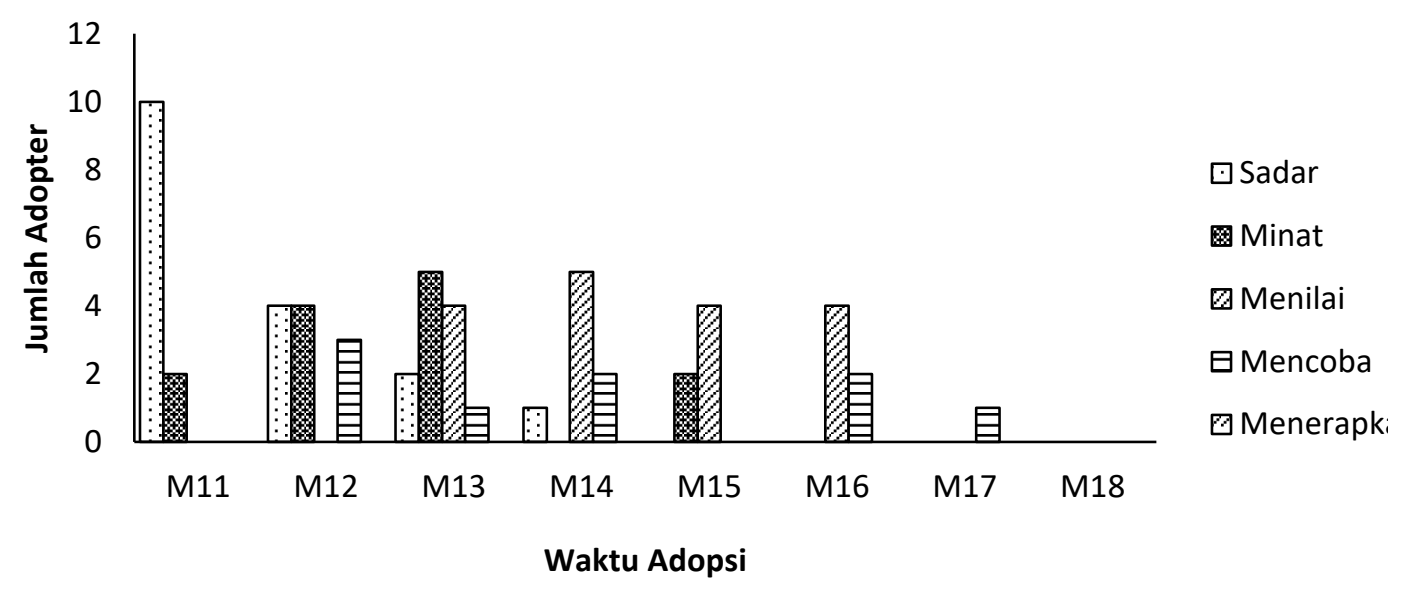

Gambar 8.Jumlah Adopter Inovasi dalam Satuan Minggu

\section{Adopsi Inovasi Demonstrasi Cara} Pembuatan Olahan Krispi Ikan

Tingkat adopsi inovasi demonstrasi cara pembuatan olahan krispi ikan dapat dilihat pada Gambar 8.

\section{Pembahasan}

Karakteristik Sasaran

Hasil penyuluhan berupa adanya perubahan sikap, pengetahuan dan keterampilan sasaran penyuluhan tergantung kepada karakteristik individu sasaran penyuluhan. Karakteristik individu adalah sifat-sifat yang ditampilkan seseorang yang dapat berhubungan dengan semua aspek kehidupannya di dunia atau lingkungan sendiri (Yani, E.S, dan Noviyanti 2010).

Terdapat beberapa kategori karakteristik sasaran, yaitu kategori muda kurang dari pada usia 39 tahun, kategori usia sedang dengan kisaran usia 40-53 tahun dan kategori usia tua dengan rentang usia 54 tahun keatas. Sasaran penyuluhan di Kecamatan Morotai memiliki kategori usia yang beragam diantaranya 3 orang sasaran yang masuk dalam kategori muda serta 
merupakan usia produktif, 3 orang sasaran termasuk dalam kategori sedang dan terdapat 4 sasaran dalam kategori tua. Seseorang yang masih berusia muda termasuk dalam usia produktif sehingga mampu menjalankan aktifitas keseharian sesuai pekerjaannya dan memilki kemauan untuk mempelajari hal-hal baru, serta dapat berinteraksi dengan masyarakat komunitas lain (Noviyanti 2017).

Undang-Undang Nomor 20 Tahun 2003 Tentang Sistem Pendidikan Nasional mengkategorikan tingkatan pendidikan dengan tiga tingkatan diantaranya pendidikan dasar/rendah yaitu SD-SMP/MTs, pendidikan menengah yaitu SMA/SMK dan pendidikan tinggi yaitu D3-D4/S1. Adapun tingkat pendidikan sasaran yang termasuk dalam kategori rendah berjumlah 6 orang dan kategori sedang berjumlah 4 orang. Semakin tinggi tingkat pendidikan maka semakin tinggi produktivitas dan semakin cepat daya serap akan suatu inovasi (Setiawan 2010)

Kategori pengalaman usaha dapat dibagi dalam kategori pengusaha baru dengan lama usaha kurang dari setahun, pengalaman usaha sedang $1-7$ tahun dan pengusaha lama diatas tujuh tahun. Sasaran penyuluhan pada penelitian ini termasuk dalam lama usaha sedang berjumlah 10 orang. Sehingga dapat dikatakan jika sasaran telah memiliki pengalaman usaha yang cukup (Vijayanti et al. 2016). Besar kecilnya pendapatan seseorang dipengaruhi oleh beberapa faktor salah satunya yaitu penglaman usaha serta sebagai penentu dari pendapatan, khususnya pada sektor informal (Priyandikha 2015).

\section{Demonstrasi Cara pengolahan Nugget} Ikan Tuna

\section{Penyuluhan dilakukan meng-} gunakan metode demonstrasi cara pengolahan nugget dan krispi ikan tuna dilaksanakan pada sasaran yaitu Kelompok Datepi. Media yang digunakan adalah media tertayang berupa video cara pengolahan nuget. Video adalah alat bantu atau media penyuluhan yang dapat menunjukkan kembali gerakangerakan, pesan-pesan dengan menggunakan efek tertentu sehingga dapat memperkokoh proses pembelajaran dan dapat menarik perhatian penonton (Adha, Wulandari, dan Himawan 2016). Penentuan pengolahan nugget dan krispi ikan merupakan hasil dari identifikasi potensi dan peminatan dari kelompok yang telah dilakukan sebelumnya. Olahan ikan ini merupakan variasi dari bahan baku ikan tuna, yang sebelumnya hanya diolah menjadi abon ikan tuna. 
Evaluasi Aspek Pengetahuan Demonstrasi Cara pengolahan Nugget Ikan Tuna

Nilai awal (Pre Test) terendah diperoleh Ibu Nabsia dengan nilai 5, sedangkan nilai awal (Pre Test) tertinggi diperoleh Ibu Nursuni dengan nilai 11. Nilai akhir tertinggi diperoleh oleh lbu Kiran dan Nursuni dengan nilai 14. Secara keseluruhan peningkatan dan perubahan pengetahuan sebesar $26,41 \%$ dan peningkatan tertinggi diperoleh oleh Ibu Nabsia sebanyak $35,71 \%$.

Terdapat keterkaitan antara karakteristik usia dan tingkat pendidikan terhadap pengetahuan awal sasaran dan tingkat penyerapan materi inovasi yang diberikan. Sasaran yang berusia sedang dan memiliki tingkat pendidikan lebih tinggi memiliki nilai Pre Test dan Post Test yang lebih tinggi dibanding yang lainnya, contohnya Ibu Nursuni dan Ibu Kiran. Faktor-faktor yang mempengaruhi tingkat pengetahuan, sikap dan praktik seseorang diantaranya intelegensia, pendidikan, pengalaman, usia, tempat tinggal, pekerjaan, tingkat ekonomi, sosial budaya dan informasi (Kusumawardani 2012).

Evaluasi Aspek Sikap Demonstrasi Cara Pengolahan Nuget Ikan Tuna

Tahap Pre Test sebelumnya didapatkan nilai sasaran yang masih ragu-ragu sebesar $7 \%$ dan sangat tidak setuju sebesar 1\%. Namun setelah pelaksanaan penyuluhan tidak terdapat sasaran yang berada pada tingkat raguragu dan sangat tidak setuju. Perubahan sikap sasaran tersebut dipengaruhi oleh inovasi yang telah di terima. Hal yang baru akan mempengaruhi ketertarikan seseorang ketika hal tersebut dianggap bermanfaat dan memberi keuntungan bagi dirinya (Efendi dan Yudhati, 2017).

\section{Evaluasi Aspek Keterampilan Demonstrasi Cara Pengolahan Nuget Ikan Tuna}

Tabel 4 menunjukkan terdapat beberapa sasaran yang tidak terampil dalam mengolah nugget ikan. Tahap keterampilan membuat adonan surimi dan pengambilan keputusan kapan adonan selesai dikukus, sebanyak 7 orang sasaran dinyatakan belum terampil. Hal ini dikarenakan sasaran yang bingung dan umur sasaran yang sudah masuk pada kategori sedang untuk pemahaman tersebut. Umur atau usia seseorang berhubungan dengan kemampuan, kemauan belajar, dan fleksibilitas. Umur juga berhubungan dengan pengalaman, artinya umur yang tua relatif memiliki pengalaman yang lebih dibandingkan dengan yang muda (Helmy et al. 2016). Penilaian Post Test yang dilaksanakan setelah aksi penyuluhan, didapatkan hasil yang berbeda dimana sasaran semakin terampil akan inovasi yang diberikan. 
Hasil dari evaluasi akhir pada aspek keterampilan didapatkan perubahan keterampilan sasaran dari sebelumnya tidak terampil menjadi terampil. Tingkat keterampilan tertinggi yaitu pada pengambilan keputusan pada saat adonan selesai dikukus. Sebelumnya pada tahap ini banyak sasaran yang tidak mengetahui dan memahami waktu dan bentuk olahan nugget pada saat telah matang sehingga tidak ada yang terampil. Setelah dilaksanakannya aksi penyuluhan maka 9 dari 10 sasaran telah terampil melakukannya.

\section{Adopsi Inovasi Demonstrasi Cara} Pengolahan Nuget Ikan Tuna

Inovasi yang diberikan kepada sasaran dipengaruhi oleh beberapa hal baik berupa sifat inovasi, sifat adopter dan sifat pengantar prilaku perubahan. Tentunya beberapa hal tersebut akan mempengaruhi kecepatan suatu inovasi untuk diadopsi oleh sasaran (Flora K. Sinurat 2016).

Gambar 4 menunjukkan tingkat adopsi inovasi pada kegiatan penyuluhan melalui media video demonstrasi cara pembuatan olahan nugget ikan didapatkan hasil sebagai berikut: (a) Pada minggu kelima setelah dilaksanakannya kegiatan penyuluhan terdapat 10 sasaran yang sadar akan diersivikasi olahan ikan berupa nugget ikan. (b) Pada minggu keenam telah terdapat hasil yang bervariasi dimana lima orang masih di tahap sadar, tiga orang meningkat ke tahap minat dan tiga orang ke tahap mencoba yaitu lbu Fatmawati, Ibu Nursuni dan Ibu Nuryani. (c) Pada minggu ke tujuh terdapat dua orang masih pada tahap sadar, empat orang sasaran yang sebelumnya di tahap sadar meningkat ke tahap minat. Tiga orang sasaran yang sebelumnya di tahap minat pada minggu ini telah meningkat dimana empat orang di tahap menilai dan satu orang mulai mencoba yaitu lbu Fatmawati. (d) Pada minggu kedelapan masih terdapat satu orang pada tahap sadar yaitu Ibu Nuryani, empat orang yang sebelumnya di minggu ketujuh pada tahap minat telah meningkat ke tahap menilai dan bertambah menjadi lima orang dan 2 orang ditahap mencoba yaitu Ibu Fatmawati dan Ibu Nuryani. (e) Pada minggu kesembilan masih tetap sama di minggu sebelumnya hanya saja sasaran yang mencoba ada yang sama dan berbeda dari sebelumnya yaitu Ibu Hasmah. (f) Pada minggu kesepuluh terdapat tiga orang yang menilai yaitu lbu Mahmidar, Kiran dan Nursuni. Pada tahap mencoba di minggu ini terdapat dua orang sasaran yaitu lbu Fatmawati dan Nursuni.

Hasil dari kegiatan ini didapatkan bahwa belum ada sasaran yang menerapkan pembuatan olahan nugget dan krispi ikan sebagai kegiatan 
usahanya maupun memproduksi dalam skala besar. Keadaan saat ini yang terjadi adalah berkurangnya pembeli. Hal ini mengakibatkan penurunan jumlah penjualan. Upaya yang dilakukan untuk menekan biaya produksi adalah kelompok Datepi hanya memproduksi olahan ikan jika terdapat pesanan dari pembeli.

\section{Demonstrasi Cara Pembuatan Olahan Krispi lkan}

Penyuluhan demonstrasi cara pembuatan olahan krispi ikan dilakukan dengan menggunakan video yang dimana video adalah alat bantu atau media penyuluhan yang dapat menunjukkan kembali gerakan-gerakan, pesan-pesan dengan menggunakan efek tertentu sehingga dapat memperkokoh proses pembelajaran dan dapat menarik perhatian penonton (Adha et al. 2016).

\section{Evaluasi Aspek Pengetahuan} Demonstrasi Cara Pembuatan Olahan Krispi Ikan

Nilai awal (Pre Test) terendah diperoleh Ibu Siti Aisya, Mahmidar, Ati, Ratna dan Nabsia dengan nilai 5, sedangkan nilai awal (Pre Test) tertinggi diperoleh lbu Nursuni dengan nilai 7 . Adapun nilai akhir tertinggi diperoleh oleh Ibu Fatmawati, Ati, Nuryani, dan Nursuni dengan nilai 10. Secara keseluruhan peningkatan dan perubahan pengetahuan sebesar $37,0 \%$ dan peningkatan tertinggi diperoleh oleh lbu Ati Larat sebanyak 50\%.

Terdapat keterkaitan antara karakteristik usia dan tingkat pendidikan terhadap pengetahuan awal sasaran dan tingkat penyerapan materi inovasi yang diberikan. Sasaran yang berusia sedang dan memiliki tingkat pendidikan lebih tinggi memiliki nilai Pre Test dan Post Test yang lebih tinggi dibanding yang lainnya seperti Ibu Nursuni dan Ibu Kiran. Faktor-faktor yang mempengaruhi tingkat pengetahuan, sikap dan praktik seseorang diantaranya intelegensia, pendidikan, pengalaman, usia, tempat tinggal, pekerjaan, tingkat ekonomi, sosial budaya dan informasi (Kusumawardani 2012).

\section{Evaluasi Aspek Sikap Demonstrasi Cara} Pembuatan Olahan Krispi lkan

Hasil evaluasi akhir sikap sasaran mengalami perubahan pada tingkat persetujuan. Sebelumnya tingkat persetujuan sasaran memiliki nilai sebesar 33,2 (66,4\%) atau berada pada tingkat setuju. Setelah dilaksanakannya penyuluhan olahan krispi ikan dan evaluasi akhir didapatkan perubahan sikap sasaran dengan nilai menjadi 40,2 $(80,4 \%)$ atau berada pada tingkat sangat setuju dengan kisaran nilai 40 - 50 .

Pada tahap Pre Test didapatkan sasaran yang masih ragu-ragu sebesar $30 \%$ dan sangat tidak setuju sebesar 19\%. Namun setelah pelaksanaan 
penyuluhan video demcar sasaran yang ragu-ragu turun menjadi $12 \%$ dan tidak setuju menjadi 9\%. Perubahan sikap sasaran tersebut dipengaruhi oleh inovasi yang telah di terima. Hal yang baru akan mempengaruhi ketertarikan seseorang ketika hal tersebut dianggap bermanfaat dan memberi keuntungan bagi dirinya (Efendi dan Yudhati, 2017).

Evaluasi Aspek Keterampilan Demonstrasi Cara Pembuatan Olahan Krispi lkan

Tabel 6 menunjukkan terdapat beberapa sasaran yang tidak terampil dalam mengolah krispi ikan. Pada bagian sasaran mampu membuat krispi $500 \mathrm{gr}$ dengan cepat dan tepat masih banyaknya sasaran yang belum terampil sebanyak 6 orang. Hal ini dikarenakan sasaran yang bingung dengan bahan yang ingin dicampurkan dan umur sasaran yang sudah masuk pada kategori sedang untuk pemahaman tersebut. Umur atau usia seseorang berhubungan dengan kemampuan, kemauan belajar, dan fleksibilitas. Umur juga berhubungan dengan pengalaman, artinya umur yang tua relatif memiliki pengalaman yang lebih dibandingkan dengan yang muda (Helmy et al. 2016).

Hasil dari evaluasi akhir pada aspek keterampilan didapatkan perubahan keterampilan sasaran dari sebelumnya tidak terampil menjadi terampil. Tingkat keterampilan tertinggi yaitu pada sasaran mampu membuat krispi dengan cepat dan tepat. Setelah dilaksanakannya aksi penyuluhan maka 8 dari 9 sasaran telah terampil melakukannya. Beberapa sasaran masih pada tahap belum terampil di beberapa penilaian. Hal ini di sebabkan karena usia dari sasaran tersebut lebih tua dari sasaran lainnya sehingga proses penyampaian materi kurang diserap dengan baik.

\section{Adopsi Inovasi Demonstrasi Cara Pembuatan Olahan Krispi Ikan}

Inovasi yang diberikan kepada sasaran akan dipengaruhi oleh beberapa hal baik berupa sifat inovasi, sifat adopter dan sifat pengantar perilaku perubahan. Tentunya beberapa hal tersebut akan mempengaruhi kecepatan suatu inovasi untuk diadopsi oleh sasaran (Flora K. Sinurat 2016).

Gambar 8 menunjukkan tingkat adopsi inovasi pada kegiatan penyuluhan video demonstrasi cara olahan krispi ikan didapatkan hasil terjadi perubahan tingkat adopsi inovasi. Pada minggu kesebelas setelah dilaksanakannya kegiatan penyuluhan terdapat 10 sasaran yang sadar akan diversifikasi olahan ikan krispi ikan tuna dan ada 2 orang juga yang sudah mulai minat. Pada minggu kedua belas telah terdapat hasil yang bervariasi dimana empat orang masih di tahap sadar, empat orang tersebut meningkat ke tahap minat dan tiga orang ke tahap mencoba yaitu Ibu 
Fatmawati, Ibu Nursuni dan Ibu Nuryani. Pada minggu ketiga belas terdapat dua orang masih pada tahap sadar, lima orang sasaran meningkat ke tahap minat. Tiga orang sasaran yang sebelumnya di tahap minat pada minggu ini telah meningkat dimana empat orang di tahap menilai dan satu orang mulai mencoba yaitu Ibu Fatmawati. Pada minggu keempat belas masih terdapat satu orang pada tahap sadar yaitu lbu Fatmawati Fabanyo, lima orang telah meningkat ke tahap menilai dan 2 orang ditahap mencoba yaitu Ibu Fatmawati dan Ibu Nuryani. Pada minggu kelimabelas terdapat dua orang pada tahap minat dan 4 orang ditahap menilai. Pada minggu keenambelas terdapat empat orang yang menilai yaitu lbu Mahmidar, Kiran, Nursuni dan Nuryani. Pada tahap mencoba di minggu ini terdapat dua orang sasaran yaitu lbu Fatmawati dan Nursuni. Pada minggu ketujuhbelas hanya terdapat satu orang yaitu lbu Fatmawati pada tahap mencoba.

Hasil dari kegiatan ini didapatkan bahwa belum ada sasaran yang menerapakan olahan krispi ikan sebagai kegiatan usahanya maupun produksi secara skala besar. Hal ini disebabkan oleh adanya pandemik Covid-19 yang telah menjangkit daerah Kabupaten Pulau Morotai. Adapun 1 kelompok yang susah untuk dijangkau sekarang karena adanya pandemik jadi penulis hanya akan berfokus pada 1 kelompok saja. Menurut keterangan sasaran bahwa sepinya pembeli mengakibatkan penurunan penjualan sehingga cukup sulit untuk mengadopsi olahan tersebut. Sehingga dalam menekan biaya produksi, kelompok Datepi hanya memperoduksi jika terdapat pesanan dari pembeli. Adapun olahan krispi ikan dijadikan sebagai makanan keluarga sebagai lauk makanan.

\section{SIMPULAN DAN SARAN}

Penyuluhan melalui metoda demontrasi cara pembuatan olahan nugget ikan tuna dapat meningkatkan pengetahuan, sikap dan keterampilan sasaran yaitu Poklahsar Datepi, Kecamatan Morotai Selatan, Kabupaten Morotai. Terjadi peningkatan aspek pengetahuan sasaran sebesar $26,41 \%$, peningkatan aspek sikap sebesar $13,6 \%$ dan pada aspek keterampilan terjadi peningkatan dimana yang sebelumnya tidak terampil menjadi terampil. Demikian pula pada demonstrasi cara pembuatan olahan krispi ikan tuna, terjadi peningkatan aspek pengetahuan sebesar $37 \%$, peningkatan aspek sikap sebesar $14 \%$ dan aspek keterampilan terjadi peningkatan dimana yang sebelumnya tidak terampil menjadi terampil. Adopsi inovasi baik diversifikasi olahan nuget dan krispi ikan tuna dicapai 
hingga pada tahap mencoba dengan jumlah sasaran yang mencoba sebanyak tiga orang. Penyuluhan diversifikasi olahan ikan tuna merupakan inovasi baru bagi Poklahsar Datepi dan dapat diadopsi dengan baik hingga tahap mencoba.

Penyuluhan terkait diversifikasi olahan hasil perikanan perlu ditingkatkan melihat tingginya keinginan sasaran untuk menguasai teknologi tersebut. Sasaran dapat memanfaatkan bahan baku ikan yang berlimpah untuk meningkatkan pengetahuan dan keterampilan dengan melatih dalam mengolah berbagai jenis produk olahan dengan mengikuti perkembangan teknologi dan informasi.

\section{DAFTAR PUSTAKA}

Adha, A., D. Wulandari, dan A. Himawan. 2016. "Perbedaan Efektivitas Pemberian Penyuluhan Dengan Video Dan Simulasi Terhadap Tingkat Pengetahuan Pencegahan Tb Paru (Studi Kasus Di MA Husnul Khatimah Kelurahan Rowosari Kecamatan Tembalang Kota Semarang)." Jurnal Kedokteran Diponegoro 5(4):56579.
Amdar, Anwar Akbar, Pigoselpi Anas, dan Tatty Yuniarti. 2019. "Analisis Usaha Beberapa Produk Olahan Perikanan di CV. Fania Food Kota Gede Daerah Istimewa Yogyakarta." Jurnal Penyuluhan Perikanan dan Kelautan 13(2):225-42. doi: 10.33378/jppik.v13i2.196.

BPS. 2017. Kabupaten Morotai Dalam Angka. Jakarta (ID): Badan Pusat Statistik.

Efendi, Marwan, dan Miranti Yudhati. 2017. "Pengaruh Ekspektasi Laba terhadap Minat Berwirausaha (Studi pada Mahasiswa Angkatan 2013 STIE MBI Jakarta)." Jurnal Administrasi dan Kebijakan Publik 7(2):42-64. doi: 10.33558/akp.v7i2.606.

Flora K. Sinurat, Dayana. 2016. "Komunikasi Penyuluhan dan Adopsi Inovasi." PERSPEKTIF 1(2):111-23. doi: 10.31289/perspektif.v1i2.87. 
Helmy, Zahron, Sumardjo, Ninuk Purnaningsih, dan Prabowo Tjitropranoto. 2016. "Hubungan Kompetensi Penyuluh dengan Karakteristik Pribadi, Persepsi Penyuluh terhadap Dukungan Kelembagaan dan Persepsi Penyuluh terhadap Sifat Inovasi Cyber Extension." Jurnal Agro Ekonomi 31(1):1-18. doi: 10.21082/jae.v31n1.2013.1-18.

Kusumawardani, Erika. 2012. "Pengaruh

Penyuluhan Kesehatan Terhadap

Tingkat Pengetahuan, Sikap dan

Praktik Ibu dalam Pencegahan Demam Berdarah Dengue Pada Anak." Jurnal Media Medika Muda $1-15$.

Noviyanti, R. 2017. "Peran Penyuluh Bagi Nelayan Di Kelurahan Palabuhanratu Kabupaten

Sukabumi." Berkala Perikanan

Terubuk 45(2):96-102. doi: 10.31258/terubuk.45.2.96-102.

Nursahla, Nursahla, Tatty Yuniarti, Herry Maryuto, dan Dedi Sutarso. 2019.

"Adopsi Inovasi Probiotik pada Kolam Dempond Pendederan Ikan Mas (Cyprinus carpio) di Kelompok 'Mina Pojok Jaya' Kecamatan Subang." Jurnal Penyuluhan Perikanan dan Kelautan 13(2):121-37. doi: 10.33378/jppik.v13i2.194.
Priyandikha, Akhbar Nurseta. 2015. Analisis Pengaruh Jarak, Lama Usaha, Modal, dan Jam Kerja terhadap Pendapatan Pedagang Kaki Lima Konveksi (Studi Kasus di Kelurahan Purwodinatan Kota Semarang). [Skripsi]. Semarang: Universitas Diponegoro.

Putri, Jasmine Addinda, Tatty Yuniarti, dan Ita Junita Puspa Dewi. 2019. "Analisa Permasalahan Penyuluhan Perikanan di Kecamatan Cigasong Kabupaten Majalengka." Jurnal Penyuluhan Perikanan dan Kelautan 13(2):149-68. doi: 10.33378/jppik.v13i2.115.

Setiawan, A. dan S. 2010. Pengaruh Umur, Pendidikan, Pendapatan, Pengalaman Kerja dan Jenis Kelamin terhadap Lama Mencari Kerja bagi Tenaga Kerja Terdidik di Kota Magelang. [Skripsi]. Semarang: Universitas Diponegoro.

Vijayanti, Made Dwi, dan I. Gusti Wayan Murjana Yasa. 2016. "Pengaruh Lama Usaha dan Modal Terhadap Pendapatan dan Efisiensi Usaha Pedagang Sembako di Pasar Kumbasari." E-Jurnal Ekonomi Pembangunan 5(12):1539-66. 
Yani, Diarsi Eka, Ludivica E.S, dan Rinda

Noviyanti. 2010. "Presepsi

Anggota Terhadap Peran

Kelompok Tani Dalam

Meningkatkan Kemampuan

Penguasaan Teknologi Budidaya

Belimbing." Matematika, Sains, dan Teknologi (JMST) 11(2):133-

45. 